\title{
ANALISIS RASIO KEUANGAN UNTUK MEMPREDIKSI TINGKAT LABA PADA PERUSAHAAN SUBSEKTOR OTOMOTIF DAN KOMPONEN DI BEI TAHUN 2010 SAMPAI 2016
}

\author{
Abdul Majid \\ Universitas Singaperbangsa Karawang \\ email : majid@kohwa-pi.co.id
}

\begin{abstract}
The purpose of this study was to examine the effect of Working Capital to Total Asset (WCTA), Current Liabilities To Inventory (CLI), Operating Income to Total Assets (OITL), Total Asset Turnover (TAT), Net Profit Margin (NPM) and Gross Profit Margin (GPM) to the profit rate.

Data obtained by purposive sampling method with criterion (1) Automotive Manufacturing Company and Component which listed in Indonesia Stock Exchange (BEI) and consistent exist during period of research (2010 until 2016), (2) Automotive Company and Component that provide financial statement data during the study period (2010 to 2016).

The results of the analysis show that the data used in this study has met the classical assumptions, which include: no multicollinearity symptoms, no autocorrelation, no heteroscedasticity symptoms, and normal distributed data. The research was conducted by using descriptive and verification methods, namely; collecting, presenting, analyzing and testing hypotheses, and making conclusions and suggestions.

From the results of the analysis of research data, obtained the following conclusions: partially positively insignificant to profit growth: Working Capital to Total Assets (WCTA), Current Liability to Inventory (CLI), Operating Income to Total Liability (OITL), Total Asset Turnover (TAT), Partially significant positive effect on profit growth: Net Profit Margin (NPM), Partially negatively insignificant to profit growth: Gross Profit Margin (GPM). Simultaneously, the ratio of WCTA, CLI, OITL, TAT, NPM and GPM have a significant influence on Profit level. Contribution given by WCTA, CLI, OITL, TAT, NPM and GPM variable to profit rate equal to $62,9 \%$. Continuity of this research further needs to be done to see the consistency of Ratio results to Profit level for the coming year or other subsector in BEI.
\end{abstract}

Keywords: Working Capital to Total Assets (WCTA), Current Liabilities To Inventory (CLI), Operating Income to Total Assets (OITL), Total Asset Turnover (TAT), Net Profit Margin (NPM), Gross Profit Margin (GPM) and profit growth.

\section{Latar Belakang Penelitian}

Setiap perusahaan senantiasa menginginkan usahanya berkembang. Perkembangan tersebut akan terjadi apabila didukung oleh adanya kemampuan manajemen dalam menetapkan kebijakan dalam merencanakan, mendapatkan serta memanfaatkan dana-dana untuk memaksimumkan nilai-nilai perusahaan. Perusahaan sebagi entitas ekonomi umumnya memiliki tujuan jangka pendek dan jangka panjang. Tujuan jangka pendek perusahaan yaitu memperoleh laba secara maksimal, sementara 
tujuan jangka panjang perusahaan adalah memaksimalkan nilai perusahaan (Meythi, 2005)

Brigham dan Enhardt (2011) menyatakan bahwa informasi akuntasi mengenai kegiatan operasi perusahaan dan posisi keuangan perusahaan dapat diperoleh dari laporan keuangan. Informasi akuntansi dalam laporan keuangan sangat penting bagi para pelaku bisnis seperti investor dalam pengambilan keputusan. Para investor akan menanamkan investasinya pada perusahaan yang dapat memberikan return yang tinggi.

Menurut penelitian Takarini dan Ekawati (2003) rasio likuiditas yang berpengaruh positif signifikan terhadap pertumbuhan laba satu tahun mendatang adalah Working Capital to Total Asset (selanjutnya disebut WCTA). WCTA menunjukkan rasio antara modal kerja (yaitu aktiva lancar dikurangi hutang lancar) terhadap total aktiva. WCTA yang semakin tinggi menunjukkan semakin besar modal kerja yang diperoleh perusahaan dibanding total aktivanya. Dengan modal kerja yang besar, maka kegiatan operasional perusahaan menjadi lancar sehingga pendapatan yang diperoleh meningkat dan ini mengakibatkan laba yang diperoleh meningkat. Akan tetapi penelitian yang dilakukan Mahfoedz Suwarno (2004) menunjukkan bahwa WCTA tidak berpengaruh signifikan terhadap pertumbuhan laba satu tahun mendatang.

Machfoedz dalam Hapsari (2007) dalam penelitiannya menunjukkan bahwa rasio leverage yang berpengaruh signifikan terhadap pertumbuhan laba adalah Current Liabilityto Inventory (selanjutnya disebut CLI) dan Operating Income to Total Liabilities(selanjutnya disebut OITL). OITL merupakan rasio antara laba operasi sebelum bunga dan pajak (yaitu hasil pengurangan dari penjualan bersih dikurangi dengan harga pokok penjualan dan biaya operasi) terhadap total hutang (Riyanto, 2015). Semakin besar OITL, menunjukkan bahwa pendapatan yang diperoleh dari kegiatan penjualan besar dibanding total hutangnya, artinya perusahaan mampu membayar hutang-hutangnya. Ou (1990) menunjukkan bahwa rasio aktivitas yang berpengaruh signifikan untuk memprediksi pertumbuhan laba adalah Total Assets Turnover (selanjutnya disebut TAT). TAT merupakan perbandingan antara penjualan bersih (net sales) terhadap total asset.

Tahun 2010 sampai 2014 kondisi perekonomian di Indonesia mengalami perkembangan cukup baik, data Gaikindo untuk penjualan mobil meningkat dari 764.710 th 2010 menjadi 1.208 .028 th 2014 , sehingga pertumbuhan laba diharapkan meningkat .Kemudian penjualan mobil 2015 , turun menjadi 1.098 .780 dan tahun 2016 penjualan meningkat lagi menjadi 1.177.797. Fenomena pada tahun 2010 sampai dengan 2014, tidak semua rasio keuanganyang meliputi WCTA, CLI, OITL, GPM, NPM dan TAT dapat digunakan untuk memprediksi tingkat laba. Tingkat laba perusahaan manufaktur sub Otomotive dan komponen tahun 2010 sampai dengan 2011. Tingkat laba mengalami penurunan kecuali AI , hal ini mengindikasikan bahwa persaingan bisnis sangat ketat serta kelebihan kapasitas produksi berdampak negatif terhadap laba usaha.

Rasio WCTA tahun 2010 sampai dengan 2011 dari lima perusahaan manufaktur cenderung menurun kecuali AI dan GT, hal tersebut diikuti dengan tingkat laba laba yang turun juga kecuali AI. Ini berarti modal kerja yang tinggi tidak selau dapat meningkatkan laba perusahaan.

Rasio CLI dari tahun 2010 sampai dengan 2011 semuanya naik kecuali AI, kenaikan CLI inidiikuti dengan tingkat laba yang menurun kecuali AI. Ini 
menunjukkan bahwa perusahaan sudah ada yang mampu mengelola hutang lancarnya untuk meningkatkan laba perusahaan. Rasio OITL tahun 2010 sampai dengan 2011 dari lima perusahaan manufaktur semuanya menurun, namun penurunan OITL tidak diikuti dengan tingkat laba yang turun seluruhnya, karena AI pertumbuhan labanya naik. Rasio TAT sebagian besar menunjukkan arah penurunan kecuali AI, dengan diikuti pertumbuhan laba yang menurun kecuali AI, Ini berarti perputaran asset-asset perusahaan untuk menghasilkan penjualan bersihnya secara cepat, sehingga dapat meningkatkan laba. Rasio NPM dari tahun 2010 sampai dengan 2011 dari lima perusahaan manufaktur sebagian besar menunjukkan penurunan kecuali AI, hal diikuti dengan pertumbuhan laba yang menurun dan juga naik utk AI. Begitu pula dengan rasio GPM yang semuanya menurun dan diikuti dengan pertumbuhan laba yang turun kecuali AI. Ini menunjukkan bahwa laba bersih dan laba kotor yang diterima perusahaan dari kegiatan penjualannya, tidak mampu meningkatkan laba perusahaan.

Berdasarkan penelitian-penelitian terdahulu (researchgap) dan fenomena yang ada, maka penelitian ini perlu dilakukan untuk menelaah pengaruh rasio-rasio keuangan (WCTA, CLI, OITL, TAT, NPM dan GPM) terhadap tingkat laba pada perusahaan manufaktur yang terdaftar di Bursa Efek Indonesia (BEI) pada periode tahun 2010 sampai dengan 2016.

\section{Perumusan Masalah}

Perumusan masalah penelitian ini adalah :

1. Bagaimana rasio keuangan WCTA, CLI, OITL, TAT, NPM dan GPM dan tingkat laba?

2. Seberapa besar pengaruh parsial WCTA, CLI, OITL, TAT, NPM dan GPM terhadap tingkat laba?

3. Seberapa besar pengaruh simultan WCTA, CLI, dan OITL, TAT, NPM dan GPM terhadap tingkat laba?

\section{Kajian Teori \\ Rasio keuangan}

Rasio keuangan menurut Sofyan Syafri Harahap (2013:297) adalah adalah angka yang diperoleh dari hasil perbandingan dari satu pos laporan keuangan dengan pos lainnya yang mempunyai hubungan yang relevan dan signifikan. Sedangkan menurut S. Munawir (2014:68) berdasarkan sumber datanya dapat dibedakan sebagai berikut :

1. Rasio- rasio neraca ( balance sheet ratio) adalah semua rasio yang semua datanya diambil dari atau bersumber pada neraca

2. Rasio- rasio laporan laba rugi ( income statement ratio) yaitu angka - angka rasio yang dalam penyusunannya semua datanya diambil dari laporan laba rugi.

3. Rasio-rasio antar laporan (inter statement ratio) ialah semua angka rasio yang penyusun datanya berasal dari neraca dan data lainnya dari laporan laba rugi.

Rasio keuangan berdasarkan ruang lingkup atau tujuan yang ingin dicapai, yaitu :

1. Rasio likuiditas ( Liquidity ratio )

Rasio ini menyatakan kemapuan perusahaan jangka pendek untuk memenuhi obligasi ( kewajiban) yang jatuh tempo.

2. Rasio solvabilitas ( Solvability ratio) 
Rasio ini menunjukkan kemampuan perusahaan untuk memenuhi kewajiban jangka panjangnya. Rasio ini juga disebut leverage ratios, karena merupakan rasio pengungkit yaitu menguunakan uang pinjaman (debt) untuk memperoleh keuntungan

3. Rasio Aktifitas (Activity ratio)

Rasio ini menunjukkan kempuan serta efisiensi perusahaan di dalam memanfatkan harta-harta yang dimilikinya.

4. Rasio Rentabilitas/Profitabilitas ( Profitability ratio)

Rasio ini menunjukkan keberhasilan perusahaan di dalam menghasilkan keuntungan.

5. Rasio pasar ( market rasio ) rasio ini menunjukkan informasi penting perusahaan yang diungkapkan dalam basis per saham.

\section{Analisis rasio keuangan}

Pengertian analisi rasio keuangan menurut James C Van Home adalah sebagai berikut :

"Analisis dan interpretasi dari macam- macam rasio dapat memberikan pandangan yang lebih baik tentang kondisi keuangan dan prestasi perusahaan bagi para analis yang ahli dan berpengalaman dibandingkan analisis yang hanya didasrkan atas data keuangan sendiri-sendiri yang tidak berbentuk rasio".

Dennis dalam Meythi ( 2005) menyatakan bahwa analisis rasio keuangan merupakan metode paling baik digunakan untuk memperoleh gambaran kondisi keuangan perusahaan secara keseluruhan. Menurut Usman (2014), analisis ini berguna sebagai analisis intern bagi manajemen perusahaan untuk mengetahui hasil keuangan yang telah dicapai guna perencanaan yang akan datang dan juga untuk analisis intern bagi kreditur dan investor untuk menentukan kebijakan pemberian kredit dan penanaman modal suatu perusahaan

Analisis rasio keuangan ini dapat dibagi atas dua jenis berdasarkan variate yang digunakan dalam analisis, yaitu :

1. Univariate Ratio Analysis

Univariate Ratio Analysis merupakan analisis rasio keuangan yangmenggunakan satu variate didalam melakukan analisis. Contohnya seperti Profit Margin Ratio, Return On Asset (ROA) dan Return On Equity (ROE).

2. Multivariate Ratio Analysis

Multivariate Ratio Analysis merupakan analisis rasio keuangan yangmenggunakan lebih dari satu variate di dalam melakukan analisis, seperti Alman's Z-Score dan Zeta Score.

Rasio keuangan merupakan perbandingan dari dua data yang terdapat dalam laporan keuangan perusahaan. Rasio keuangan digunakan kreditur untuk mengetahui kinerja suatu perusahaan dengan melihat kemampuan perusahaan dalam membayar hutang-hutangnya (Dennis, 2006).

Rasio keuangan dikelompokkan dengan istilah yang berbeda-beda, sesuai dengan tujuan analisisnya. Menurut Nugroho (2003), beberapa rasio keuangan yang sering dipakai oleh seorang analisis dalam mencapai tujuannya, yaitu rasio profitabilitas yang digunakan untuk mengukur kemampuan perusahaan memperoleh laba dalam hubungannya dengan penjualan, total aktiva maupun modal sendiri dan rasio likuiditas, untuk mengukur kemampuan perusahaan dalam memenuhi kewajiban keuangan jangka pendek tepat pada waktunya. Brigham dan Daves (2001) dalam 
Meythi (2005) menggolongkan rasio keuangan menjadi rasio likuiditas, rasio solvabilitas (leverage ratio), rasio aktivitas dan rasio profitablitas. Weygandt et. al (1996) dalam Meythi (2005) menggolongkan rasio keuangan kedalam tiga macam rasio likuiditas, profitabilitas dan solvency. Secara umum, rasio keuangan dapat dikelompokkan menjadi rasio likuiditas, rasio leverage, rasio aktivitas dan rasio profitabilitas (Riyanto,2015).

\section{Laba}

Menurut Sofyan Safri Harahap (2013:112) "Laba adalah kelebihan penghasilan diatas biaya selama satu periode akuntansi". Sedangkan menurut Suwardjono (2008:464) "Laba dimaknai sebagai imbalan atas upaya perusahaan menghasilkan barang dan jasa. Ini berarti laba merupakan kelebihan pendapatan di atas biaya (biaya total yang melekat dalam kegiatan produksi dan penyerahan barang/jasa)". Laba secara operasional merupakan perbedaan antara pendapatan yang direalisasi yang timbul dari transaksi selama satu periode dengan biaya yang berkaitan dengan pendapatan tersebut. Sedangkan pengertian laba menurut IAI 2012 adalah kenaikan manfaat ekonomi selama satu periode akuntansi dalam bentuk pemasukan atau penambahan aktiva atau penurunan kewajiban yang mengakibatkan kenaikan ekuitas yang tidak berasal dari kontribusi peranan modal. Berdasarkan pengertian di atas dapat disimpulkan bahwa laba adalah kelebihan pendapatan di atas biaya sebagai imbalan menghasilkan barang dan jasa selama satu periode akuntansi.

Selanjutnya menurut Sutrisno (2013:9) Laba terjadi apabila penghasilan yang diperoleh dalam satu periode lebih besar dibandingkan dengan biaya-biaya yang dikeluarkan. Menurut Ciaran Walsh (2012:39), Laba merupakan pendapatan total dikurangi biaya total pada periode spesifik.

Menurut Ikatan Akuntansi Indonesia (2012:12) "Penghasilan bersih (laba) sering digunakan sebagai ukuran kinerja atau dasar bagi ukuran yang lain seperti imbal hasil investasi (Return On Investment) atau laba per saham (Earning Per Share)". Kinerja perusahaan merupakan hasil dari serangkaian proses dengan mengorbankan berbagai sumber daya. Adapun salah satu parameter penilaian kinerja perusahaan tersebut adalah pertumbuhan laba. Pertumbuhan laba digunakan untuk menilai kinerja suatu perusahaan.

Laba yang digunakan dalam penelitian ini adalah laba setelah pajak (Earning After Tax), menurut Walsh( 2013:40)Total pendapatan dikurangi biaya operasional menghasilkan laba operasional. Ini laba pertama dalam laporan akuntasi. Ada banyak definisi laba berkaitan cara pendistribusian laba. Ada pos pos laba sebagai berikut :

1. EBIT ( Earning before interest and Tax) Laba sebelum bunga dan pajak

2. EBT ( Earning before Tax) Laba sebelum Pajak

3. EAT ( Earning after Tax) Laba setelah pajak

4. RE ( Retained earning ) Laba ditahan

\section{Kerangka Pemikiran}

Berdasarkan landasan teoritis, kerangka pikir dalam penelitian ini dapat digambarkan sebagai berikut : 


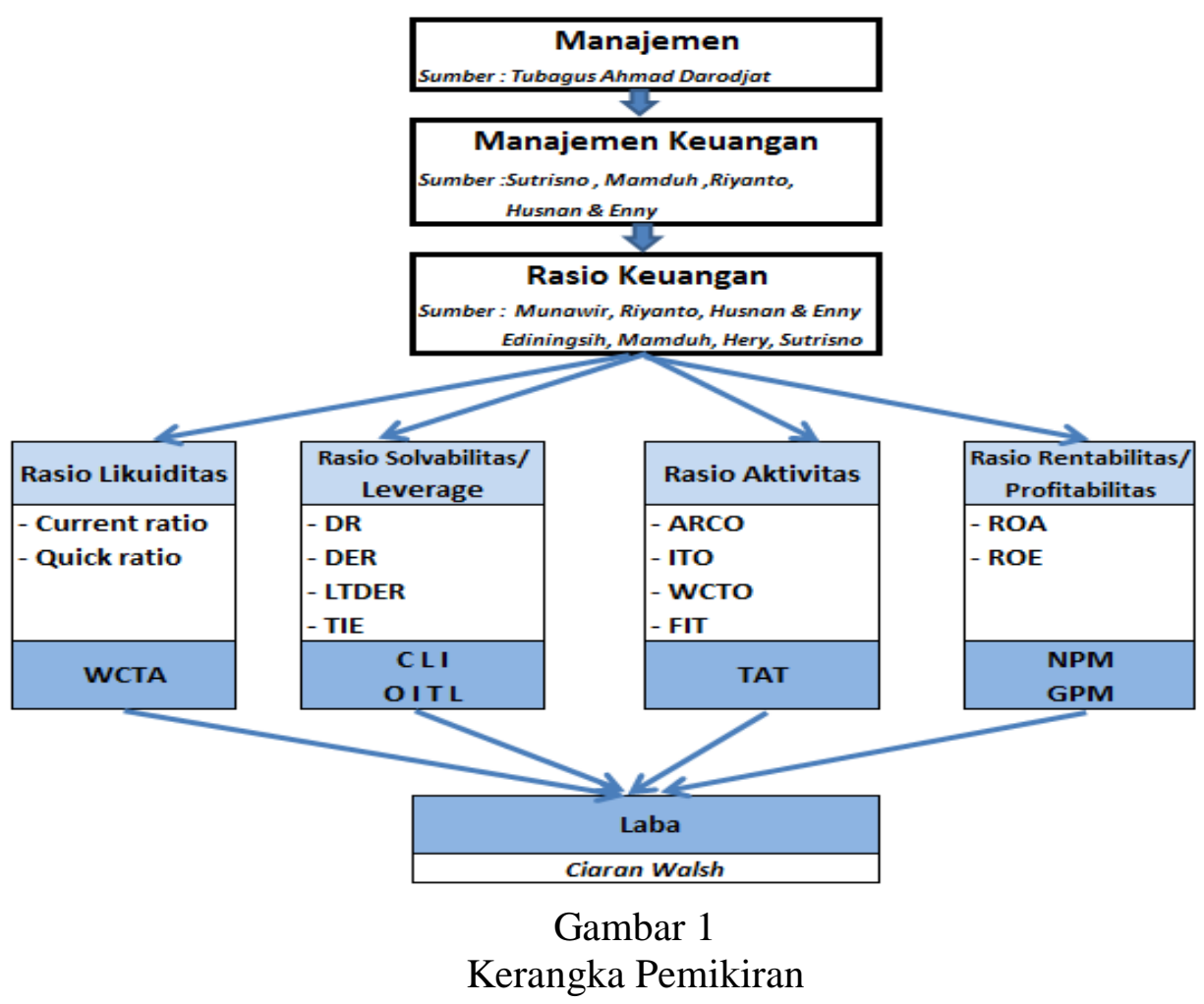

Berdasarkan teori dan hasil-hasil penelitian sebelumnya mengenai hubungan antara WCTA, CLI, OITL, TAT, NPM dan GPM dengan pertumbuhan laba maka dapat disusun paradigma pemikiran teoritis seperti pada gambar 2 .

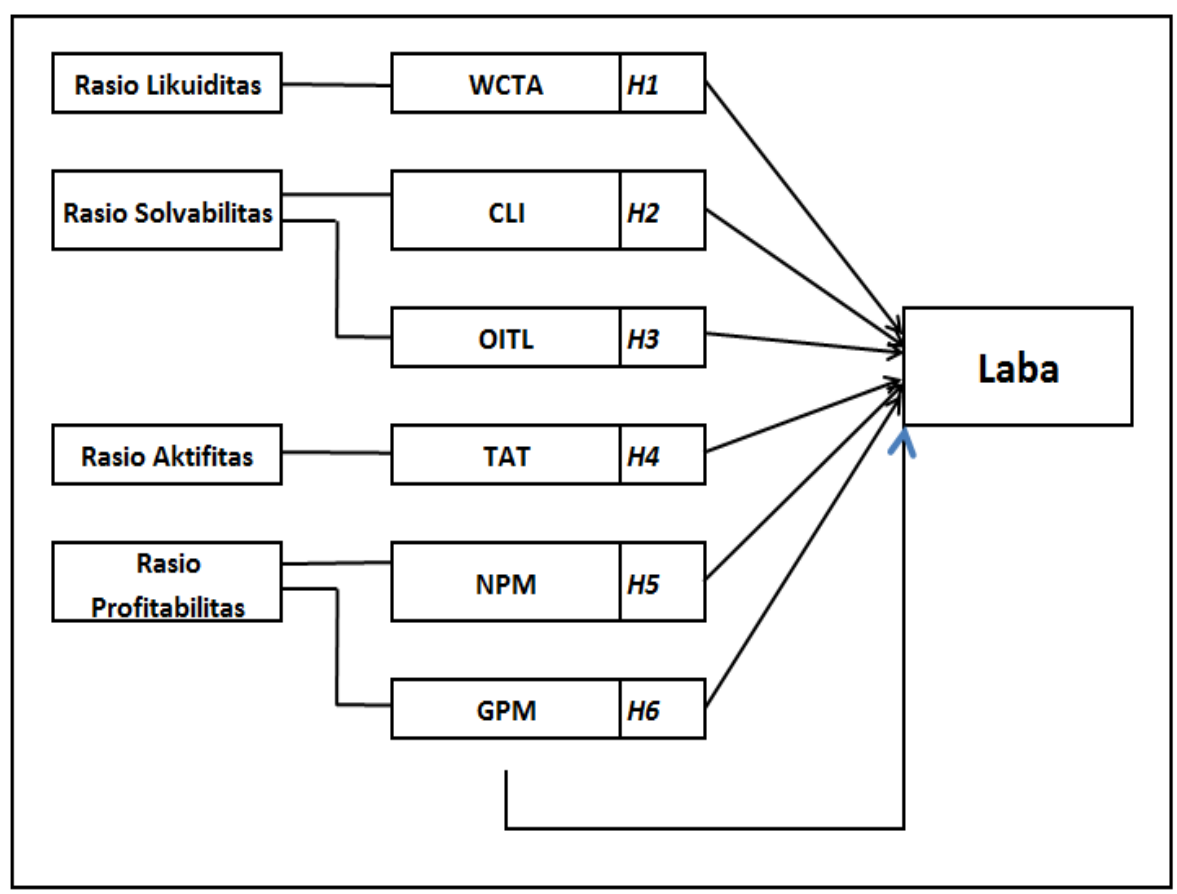

Gambar 2

Paradigma Penelitian 


\section{Metode yang digunakan}

Metode yang akan digunakan dalam penelitian ini adalah metode deskriptif dan verifikatif, karena adanya variabel-variabel yang akan ditelaah keterkaitannya. Metode deskriptif adalah suatu metode dalam menilai status kelompok manusia, suatu objek, suatu set kondisi, suatu sistem pemikiran ataupun suatu kelas peristiwa pada masa sekarang. Metode verifikatif digunakan untuk mengetahui hubungan antar variabel melalui pengujin hipotesis.

Penelitian ini akan menyajikan gambaran secara terstruktur, faktual dan akurat mengenai fakta- fakta serta hubungan antar variabel yang diteliti,yaitu pengaruh rasio WCTA, OITL, CLI, TAT, NPM dan GPM tehadap pertumbuhan laba.

Sedangkan analisis verifikatif adalah model dan pembuktian yang berguna untuk mencari kebenaran dari hipotesisi yang diajukan. Analisis verifikatif merupakan analisis untuk membuktikan dan mencari kebenaran dari hipotesis yang dilakukan. Analisis ini bermaksud untuk mengetahui hasil penelitian berkaitan dengan pengaruh rasio WCTA, OITL, CLI, TAT, NPM dan GPM tehadap pertumbuhan laba. Pendekatan dalam penelitian ini adalah pendekatan kuantitatif, karena penelitian ini disajikan dengan angka angka.

\section{Sumber dan jenis data}

Dalam penelitian ini data yang diperoleh adalah dari hasil analisa langsung terhadap dokumen dan data - datayang ada pada Bursa efek Indonesia yaitu yaitu laporan keuangan perusahaan otomotif tahun 2010 sampai denga 2016. Data yang digunakan dalam penelitian ini dikumpulkan dengan menggunakan metode historis dan secara online, berupa laporan keuangan yang berasal dari website resmi yang dimiliki oleh BEI, yaitu www.idx.co.id Data laporan keuangan yang diperlukan mencakup data tahun 2010 sampai dengan 2016.

Data dalam penelitian ini adalah kuantitatif yang merupakan data yang dapat diinput ke dalam skala pengukuran statistik. Fakta dan fenomena dalam data ini tidak dinyatakan dalam bahasa alami, melainkan dalam numerik.

\section{Cara Penentuan Data/ Informasi}

Penelitian ini menggunakan data sekunder yang berupa data rasio- rasio laporan keuangan perusahaan otomotif dan komponen yang diperoleh dari website resmi Bursa Efek Indonesia, yaitu www.idx.co.id tahun 2010 sampai dengan 2016. Data-data yang diperoleh meliputi laporan keuangan tahunan dan ringkasan laporan tahunan.

Terdapat 13 populasi perusahaan otomotif dan komponen, namun dibatasi dengan persyaratan sebagai berikut :

1. Perusahaan otomotif dan komponen yang terdaftar di BEJ dan konsisten ada selama periode penelitian (tahun 2010 sampai dengan 2016).

2. Perusahaan otomotif dan komponen yang menyediakan data laporan keuangan selama kurun waktu penelitian (tahun 2010 sampai dengan 2016).

\section{Teknik Pengumpulan Data}

Teknik pengumpulan data penelitian ini dengan menggunakan Wawancara, Observasi, Angket (kuesioner) dan Studi Dokumen 


\section{Uji Keabsahan data}

Untuk menguji hipotesis tentang kekuatan variabel penentu (independent varable) terhadap pertumbuhan profitabilitas. Maka data- data sekunder yang telah diumpulkan sebelum dilakukan pengujian hipotesa supaya memenuhi prinsipvaliditas dan reabilitas maka diperlukan persyaratan yang harus dipenuhi antara lainUji asumsi klasik.

Uji asumsi klasik diperlukan suatu penaksir (estimator) yang BLUE (Best Linier Unbiused Estimator) atau penaksir linier terbaik yang tidak bias. Untuk itu maka dalam pengujian hipotesis harus dihindari terjadinya penyimpangan asumsi klasik. Tiga asumsi klasik yang perlu diperhatikan adalah : Uji Auto Korelasi, Uji

\section{Multikolinearitas dan Uji Heteroskedastisitas}

\section{Rancangan Analisis dan Uji Hipotesis}

Rancangan analisis data penelitian ini menggunakan analisis deskriptif dan anaslisis verifikatif dengan regresi sederhana, regresi berganda dan koefisien determinasi serta melakukan uji hipotesis secara lengkap.

Regresi sederhana: $\mathrm{Y}=\mathrm{A}+\mathrm{B} \mathrm{X}$

Regresi Berganda : $\mathrm{Y}=\mathrm{A}+\mathrm{B} 1 \mathrm{X} 1+\mathrm{B} 2 \mathrm{X} 2+\mathrm{B} 3 \mathrm{X} 3+\mathrm{B} 4 \mathrm{X} 4+\mathrm{B} 5 \mathrm{X} 5+\mathrm{B} 6 \mathrm{X} 6+\mathrm{e}$

\section{Hasil Penelitian}

Karakteristik utama industri manufaktur adalah mengolah sumber daya menjadi barang jadi melalui proses fabrikasi. Aktifitas perusahaan yang tergolong dalam kelompok industri manufaktur dibagi menjadi beberapa sektor. Untuk sektor 4, aneka industri dibagi menjadi beberapa subsektor antara lain subsektor otomotif dan komponen.

Berdasarkan analisis asumsi klasik dapat disimpulkan bahawa analisis regresi sederhana dari variable WCTA (X1), CLI(X2), OITL(X3), TAT (X4), NPM (X4) dan GPM (X6) terhadap variabel dependen tingkat Laba (Y) memenuhi syarat korelasi karena :

1. Uji Normalitas Data, titik-titik menyebar data berada di sekitar garis diagonal, serta penyebarannya mengikuti arah garis diagonal. Maka model regresi ini memenuhi asumsi normalitas

2. Uji Multikolinieritas, model tregresi tersebut tidak terdapat problem multikolinieritas baik berdasar besaran korelasi antar variabel maupun besaran VIF.

3. Uji Auto Korelasi, bahwa tidak ada masalah auto korelasi

4. Uji Heterosdekastisitas, tidak terjadi heterosdekastisitas pada model regresi tersebut, sehingga model regresilayak dipakai untuk predikdi regresi

\section{Analisis Deskriptif}

Penelitian ini menggunakan data dalam bentuk pooled cross sectional.Penelitian dilakukan pada tahun 2010 sampai dengan 2016 dengan sampelsebanyak 12 perusahaan subsector otomotif dan komponen, maka secara pooled cross sectional diperoleh sejumlah 12 perusahaan $\times 7$ tahun $=84$ data observasi.Data - data yang terlalu ekstrim atau outliner dihilangkan sehingga diperoleh data akhir 45.

Variabel independen yang digunakan dalam penelitian ini adalah WCTA, CLI, OITL, TAT, NPM dan GPM, sedangkan variabel dependennya adalah tingkat laba. Data untuk variabel WCTA, CLI, OITL, TAT, NPM, GPM dan tingkat laba diperoleh 
melalui perhitungan yang diolah berdasarkan laporan keuangan tahunan yang diperoleh dari BEJ.

Berdasarkan hasil perhitungan, nampak bahwa dari 12 perusahaan dengan 45 pengamatan.meantingkat laba selama periode pengamatan (2010 sampai dengan 2016 ) sebesar 191200,5589 dengan $\delta$ sebesar 306624,2310; dimana hasil tersebut menunjukkan bahwa nilai standar deviasi $\boldsymbol{\delta}>$ meanrata - rata ingkat laba, demikian juga dengan nilai minimum yang lebih kecil dari rata-ratanya $(-313326,00)$ dan nilai maksimum yang lebih besar dari mean $(970891,00)$. Hal ini menunjukkan bahwa variabel tingkat laba mengindikasikan hasil yang kurang baik, karena $\delta$ yang mencerminkan penyimpangan dari data variabel tersebut cukup tinggi karena lebih besar dari mean.

Hasil yang sama terjadi pada variabel independen WCTA. Rata-rata WCTA selama periode pengamatan 2010 sampai dengan 2016 sebesar 7,7942 dengan $\delta=$ 8,98231 ; Untuk data variabel yang lain,mean CLI sebesar 205,618dengan $\delta=$ 63,83680; mean TAT sebesar 0,8696 dengan $\delta=0,36550$; meanOITL sebesar 11,0173dengan $\delta=6,07444$; mean NPM sebesar 3,0771 dengan $\delta=2,7779$ dan mean GPM sebesar 15,6018 dengan $\delta=3,21158$

Berdasarkan hasil perhitungan, rasio WCTA terbesar adalah 42,59 \% PT LPIN pada tahun Desember 2010 sedang terkecil $-46,70 \%$ pada PT NIPS pada Desember 2010. Rasio CLI terbesar 492,9\% pada ASII Desember 2013, terkecil 70,34\% pada INDS Desember 2012. Rasio OITL terbesar 93,96\% pada PT SMSC Desember 2014 dan terkecil 4,39\% pada PT GDYR Des 2015. Rasio TAT terbesar 1,64 pada PT GDYR Desember 2012 dan terkecil 0,23 pada PT PRAS Desember 2016. Rasio NPM terbesar19,59 \% pada PT AUTO Desember 2010 dan terkecil pada PT LPN -45.76\%. Rasio GPM terbesar pada PT LPIN 43,99\% pada Desember 2011 dan terkecil pada PT GDYR sebesar 6,76\%.

\section{Analisis Verifikatif}

Dari pengujian asumsi klasik dapat disimpulkan bahwa data yang adaterdistribusi normal, tidak terdapat multikoliniearitas, autokorelasi dan heteroskedastisitas sehingga memenuhi persyaratan untuk melakukan analisis regresi berganda.

Analisis regresi sederhana berfungsi untuk menjelaskan perannya masingmasing variabel independen WCTA(X1), CLI(X2), OITL(X3), TAT(X4), NPM(X5) dan GPM(X6) terhadap variabel dependen tingkat LABA (Y).

\section{Analisis Regresi Sederhana \\ Pengaruh sederhana WCTA, CLI, OITL, TAT, NPM, GPM terhadap LABA}

Rasio WCTA berpengaruh positif terhadap tingkat Laba perusahaan, hubungannya lemah $(\mathrm{r}=0,284)$. Rasio WCTA berpengaruh positif dalam meningkatkan LABA perusahaan secara regresi sederhana sebesar 8,0656 \% dengan demikian masih ada 91,9344 \% faktor lain yang mempengaruhi tingkat Laba perusahaan. Setiap perubahan WCTA sebesar 1 unit satuan, maka tingkat Laba perusahaan akan meningkat sebesar 9704,502 satuan.

Rasio CLI berpengaruh positif terhadap tingkat Laba perusahaan, hubungannya sangat lemah $(r=0,038)$. Rasio CLI berpengaruh positif dalam meningkatkan LABA perusahaan secararegresi sederhana sebesar $0,1444 \%$ dengan demikian masih ada $99,8556 \%$ faktor lain yang mempengaruhi tingkat Laba perusahaan. Setiap perubahan 
CLI sebesar 1 unit satuan, maka tingkat Laba perusahaan akan meningkat sebesar182,231 satuan.

Rasio OITL berpengaruh positif terhadap tingkat Laba perusahaan, hubungannya lemah $(r=0,202)$. Rasio OITL berpengaruh positif dalam meningkatkan LABA perusahaan secara regresi sederhana sebesar 4,0804 \% dengan demikian masih ada 95,9196\% faktor lain yang mempengaruhi tingkat Laba perusahaan. Setiap perubahan OITL sebesar 1 unit satuan, maka tingkat Laba perusahaan akan meningkat sebesar 10219,219 satuan.

Rasio TAT berpengaruh positif terhadap tingkat Laba perusahaan, hubungannya lemah $(\mathrm{r}=0,216)$. Rasio TAT berpengaruh positif dalam meningkatkan LABA perusahaan secara regresi sederhana sebesar 4,6656 \% dengan demikian masih ada 95,3344 \% faktor lain yang mempengaruhi tingkat Laba perusahaan. Setiap perubahan TAT sebesar 1 unit satuan, maka tingkat Laba perusahaan akan meningkat sebesar 181189,421 satuan.

Rasio NPM berpengaruh positif terhadap tingkat Laba perusahaan, hubungannya cukup kuat $(\mathrm{r}=0,599)$. Rasio NPM berpengaruh positif dalam meningkatkan LABA perusahaan secara regresi sederhana sebesar 35,8801\% dengan demikian masih ada 64,1199 \% faktor lain yang mempengaruhi tingkat Laba perusahaan. Setiap perubahan NPM sebesar 1 unit satuan, maka tingkat Laba perusahaan akan meningkat sebesar 66148,879 satuan.

Rasio GPM berpengaruh negatif terhadap tingkat Laba perusahaan, hubungannya sangat lemah $(\mathrm{r}=0,028)$. Rasio GPM berpengaruh positif dalam meningkatkan LABA perusahaan secara regresi sederhana sebesar $0,0625 \%$ dengan demikian masih ada $99.9216 \%$ faktor lain yang mempengaruhi tingkat Laba perusahaan. Setiap perubahan GPM sebesar 1 unit satuan, maka tingkat Laba perusahaan akan menurun sebesar 2650,024 satuan.

\section{Analisis Regresi Berganda}

Analisis Data Penelitian ini digunakan untuk menganalisis pengaruh variabel WCTA, CLI, OITL, TAT, NPM dan GPM pada tingkat Laba pada perusahaan subsektor Otomotif dan Komponen yang terdaftar di Bursa Efek Indonesia tahun 2010-2016 sesuai tabel 1.

Tabel 1

Analisis regresi berganda WCTA, CLI, OITL, TAT,NPM dan GPM

Terhadap Tingkat LABA

Coefficients $^{a}$

\begin{tabular}{|cl|r|r|r|r|r|}
\hline \multirow{2}{*}{ Model } & \multicolumn{2}{|c|}{ Unstandardized Coefficients } & \multicolumn{2}{c|}{$\begin{array}{c}\text { Standardized } \\
\text { Coefficients }\end{array}$} & \multicolumn{1}{c|}{} \\
\cline { 3 - 5 } & & \multicolumn{1}{|c|}{$\mathrm{B}$} & \multicolumn{1}{|c|}{ Std. Error } & \multicolumn{1}{c|}{ Beta } & \multicolumn{1}{c|}{ Sig. } \\
\hline 1 & (Constant) & $-357604,034$ & 238257,156 & & $-1,501$ &, 142 \\
& WCTA & 24540,841 & 4669,700 &, 719 & 5,255 &, 000 \\
& CLI & 1796,114 & 640,532 &, 374 & 2,804 &, 008 \\
& OITL & $-28371,262$ & 8068,862 &,- 562 & $-3,516$ &, 001 \\
& TAT & 208845,149 & 117053,637 &, 249 & 1,784 &, 082 \\
& NPM & 95387,491 & 13354,828 &, 864 & 7,143 &, 000 \\
& GPM & $-11173,749$ & 12563,093 &,- 117 &,- 889 &, 379 \\
\hline
\end{tabular}

a. Dependent Variable: LABA 
Rumus persamaan regresi berganda :

$$
\begin{aligned}
& Y=\alpha+b 1 X 1+b 2 X 2+b 3 X 3+b 4 X 4+b 5 X 5+b 6 X 6+e \\
& Y=-357604,034+97100,476 X 1+1796,114 X 2-28371,262 \times 3 \\
& +208845,149 X 4+95387,491 X 5-11173,749 X 6
\end{aligned}
$$

Sign $\quad 0,1420,0000,0080,0010,0820,0000,379$

t $\quad-1,5015,2552,804-3,5161,7847,143 \quad-0,889$

Berdasarkan perhitungan persamaan regresi berganda diatas maka dapat dijelaskan sebagai berikut :

a. Apabila tidak ada perubahan variabel X1, X2, X3, X4, X5, dan X6 atau masing masing nilainya 0 (konstan) maka tingkat Laba perusahaan nilainya turun sebesar 357604,034;

b. Apabila terjadi kenaikan terhadap variabel X1 sebesar 1 satuan, dan kondisi $\mathrm{X} 2, \mathrm{X} 3, \mathrm{X} 4, \mathrm{X} 5$ dan $\mathrm{X} 6$ pada posisi stabil tidak berubah maka variabel $\mathrm{Y}$ akan mengalami kenaikan 24540,841 kalinya dan atau sebaliknya dengan X2,X3,X4,X5 dan X6 tetap;

c. Apabila terjadi kenaikan terhadap variabel X2 sebesar 1 satuan, dan kondisi $\mathrm{X} 1, \mathrm{X} 3, \mathrm{X} 4, \mathrm{X} 5$ dan $\mathrm{X} 6$ pada posisi stabil tidak berubah maka variabel $\mathrm{Y}$ akan mengalami kenaikan 1796,114 kalinya dan atau sebaliknya dengan X1,X3,X4,X5 dan X6 tetap;

d. Apabila terjadi kenaikan terhadap variabel X3 sebesar 1 satuan, dan kondisi $\mathrm{X} 1, \mathrm{X} 2, \mathrm{X} 4, \mathrm{X} 5$ dan $\mathrm{X} 6$ pada posisi stabil tidak berubah maka variabel $\mathrm{Y}$ akan mengalami penurunan 28371,262 kalinya dan atau sebaliknya dengan $\mathrm{X} 1, \mathrm{X} 2, \mathrm{X} 4, \mathrm{X} 5$ dan X6 tetap;

e. Apabila terjadi kenaikan terhadap variabel $\mathrm{X} 4$ sebesar 1 satuan, dan kondisi $\mathrm{X} 1, \mathrm{X} 2, \mathrm{X} 3, \mathrm{X} 5$ dan $\mathrm{X} 6$ pada posisi stabil tidak berubah maka variabel $\mathrm{Y}$ akan mengalami kenaikan 208845,149 kalinya dan atau sebaliknya dengan $\mathrm{X} 1, \mathrm{X} 2, \mathrm{X} 3, \mathrm{X} 5$ dan X6 tetap;

f. Apabila terjadi kenaikan terhadap variabel X5 sebesar 1 satuan, dan kondisi $\mathrm{X} 1, \mathrm{X} 2, \mathrm{X} 3, \mathrm{X} 4$ dan $\mathrm{X} 6$ pada posisi stabil tidak berubah maka variabel $\mathrm{Y}$ akan mengalami kenaikan 95387,491 kalinya dan atau sebaliknya dengan X1,X2,X3,X4 dan X6 tetap;

g. Apabila terjadi kenaikan terhadap variabel X6 sebesar 1 satuan, dan kondisi $\mathrm{X} 1, \mathrm{X} 2, \mathrm{X} 3, \mathrm{X} 4$ dan $\mathrm{X} 5$ pada posisi stabil tidak berubah maka variabel $\mathrm{Y}$ akan mengalami penurunan 11173,749 kalinya dan atau sebaliknya dengan $\mathrm{X} 1, \mathrm{X} 2, \mathrm{X} 3, \mathrm{X} 4$ dan $\mathrm{X} 5$ tetap;

Untuk menjelaskan keeratan hubungan dan pengaruh bersama secara multiple regression dari WCTA(X1), CLI(X2), OITL(X3), TAT(X4), NPM(X5) dan $\operatorname{GPM}(\mathrm{X} 6)$ dengan tingkat laba, maka akan dijelaskan melalui analisis pada table 2.

Tabel 2

Model Summary Pengaruh Berganda WCTA, CLI, OITL, TAT, NPM dan GPM terhadapTingkat LABA 


Model Summary
\begin{tabular}{|l|c|c|c|c|}
\hline Model & R & R Square & $\begin{array}{c}\text { Adjusted R } \\
\text { Square }\end{array}$ & $\begin{array}{c}\text { Std. Error of } \\
\text { the Estimate }\end{array}$ \\
\hline 1 &, $824^{\text {a }}$ &, 679 &, 629 & 186830,3265 \\
\hline
\end{tabular}
a. Predictors: (Constant), GPM, CLI, NPM, TAT, WCTA, OITL
b. Dependent Variable: LABA

Berdasarkan hasil output pengolahan data dapat dijelaskan sebagai berikut :

a. Multiple regression ( $\mathrm{r}$ ) adalah 0,824, artinya korelasi antara variabel WCTA, CLI, OITL, TAT, NPM dan GPM dengan tingkat LABA adalah positif 0,824 . Korelasi sebesar 0,824 membuktikan bahwa hubungan antara variabel dari WCTA, CLI, OITL, TAT, NPM dan GPM dengan tingkat LABA perusahaan adalah sangat kuat;

b. Untuk menganalisis pengaruh bersama secara multiple regression digunakan Adjusted $R$ square ( Koefisien Determinasi yang sudah disesuaikan). Nilai Adjusted $R$ square 0,629atau 62,9\%. Hal ini menjelaskan bahwa kontribusi variabelWCTA, CLI, OITL, TAT, NPM dan GPM terhadap tingkat LABA perusahaan adalah sebesar $62,9 \%$ sedang sisanya 37,3\% dipengaruhi oleh faktor faktor lain yang tidak diteliti. Dengan demikian dari WCTA, CLI, OITL, TAT, NPM dan GPM apabila dilakukan bersama-sama maka akan meningkatkan kinerja perusahaan sebesar 62,9 $\%$.

\section{Pembahasan hasil penelitian}

Berdasarkan hasil dan uraian diatas akan dibahas sebagai berikut :

1. Rata-rata WCTA dari tahun 2010-2016 adalah 7,7942 sedangkan nilai maksimum untuk variabel WCTA 26,56. Standar deviasi adalah 8,98131 lebih tinggi dari rata-rata WCTA periode 2010-2016, ini menunjukkan belum stabilnya rasio WCTA pada perusahaan subsektor otomotif dan komponen yang terdaftar di Bursa Efek Indonesia 2010-2016.

Rata-rata CLI dari tahun 2010-2016 adalah 205,6180 sedangkan nilai maksimum untuk variabel CLI 340,85 . Standar deviasi adalah 63,83680 lebih rendah dari rata-rata CLI, periode 2010-2016, ini menunjukkan stabilnya rasio CLI pada perusahaan subsektor otomotif dan komponen yng terdaftar di Bursa Efek Indonesia 2010-2016.

Rata-rata OITL dari tahun 2010-2016 adalah 11,0173 sedangkan nilai maksimum untuk variabel OITL 22,69 . Standar deviasi adalah 6,07444 lebih rendah dari ratarata OITLperiode 2010-2016, ini menunjukkan stabilnya rasio OITL pada perusahaan subsektor otomotif dan komponen yng terdaftar di Bursa Efek Indonesia 2010-2016.

Rata-rata TAT dari tahun 2010-2016 adalah 0,8696 sedangkan nilai maksimum untuk variabel TAT 1,66. Standar deviasi adalah 0,36550 lebih rendah dari ratarata TATperiode 2010-2016, ini menunjukkan stabilnya rasio TAT pada perusahaan subsektor otomotif dan komponen yng terdaftar di Bursa Efek Indonesia 2010-2016.

Rata-rata NPM dari tahun 2010-2016 adalah 3,0771 sedangkan nilai maksimum untuk variabel NPM 8,77. Standar deviasi adalah 2,77719 lebih rendah dari ratarata NPMperiode 2010-2016, ini menunjukkan stabilnya rasio NPM pada perusahaan subsektor otomotif dan komponen yng terdaftar di Bursa Efek Indonesia 2010-2016. 
Rata-rata GPM dari tahun 2010-2016 adalah 15,6018 sedangkan nilai maksimum untuk variabel GPM 23,44. Standar deviasi adalah 3,21158 lebih rendah dari ratarata GPMperiode 2010-2016, ini menunjukkan stabilnya rasio GPM pada perusahaan subsektor otomotif dan komponen yang terdaftar di Bursa Efek Indonesia 2010-2016

Rata-rata LABA dari tahun 2010-2016 adalah 191200,5589 sedangkan nilai maksimum untuk variabel LABA 970861,00. Standar deviasi adalah 306624,2310 lebih tinggi dari rata-rata LABA periode 2010-2016, ini menunjukkan belum stabilnya tingkat LABA pada perusahaan subsektor otomotif dan komponen yng terdaftar di Bursa Efek Indonesia 2010-2016

2. Pengaruh WCTA, CLI, OITL, TAT,NPM dan GPM secara sendiri-sendiri maupun bersama- sama terhadap tingkat LABA perusahaan pada perusahaan subsektor Otomotif dan komponen di Bursa Efek Indonesia 2010-2016.

a. Pengaruh WCTA (Working Capital to Total asset)

Berdasarkan hasil penelitian secara regresi sederhana diperoleh bahwa WCTABerpengaruh positif terhadap tingkat LABA perusahaan, dengan hubungan lemah $(r=0,284)$.

WCTA berpengaruh positif dalam meningkatkan LABA perusahaan secara regresi sederhana sebesar $8,0656 \%$ dengan demikian masih ada faktor lain $91,9344 \%$ yang mempengaruhi tingkat laba perusahaan.

Secara teori WCTA adalah rasio pengukur kemampuan perusahaan untuk memenuhi kewajiban jangka pendek yang telah jatuh tempo (Gitman 2006:58, ) , begitu juga menurut Riyanto(2014:201) yaitu likuiditas yang berhubungan dengan kemampuan suatu perusahaan untuk memenuhi kewajiban finansialnya yang harus segera dipenuhi.

Hasil penelitian ini mendukung penelitian yang dilakukan oleh R Adi Setiawan (2011) WCTA berpengaruh tidak signifikan terhadap Laba

b. Pengaruh CLI ( Current Liability to Inventory)

Berdasarkan hasil penelitian secara regresi sederhana diperoleh bahwa CLI berpengaruh positif terhadap tingkat LABA perusahaan, dengan hubungan sangat lemah $(r=0,038)$.

CLI berpengaruh positif dalam meningkatkan LABA perusahaan secara regresi sederhana sebesar $0,1444 \%$ dengan demikian masih ada faktor lain $99,8556 \%$ yang mempengaruhi tingkat laba perusahaan.

Secara teori CLI adalah rasio untuk mengukur tingkat leverage perusahaan, yang merupakan perbandingan hutang lancar terhadap persediaan. Menurut Husna dan Enny $\mathrm{P}$ rasio ini mengukur seberapa jauh perusahaan menggunakan hutang.Hasil penelitian ini mendukung penelitian yang dilakukan oleh $\mathrm{R}$ Adi Setiawan (2011)CLI berpengaruh tidak significant terhadap pertumbuhan laba

c. Pengaruh OITL ( Operting income to Total Liability)

Berdasarkan hasil penelitian secara regresi sederhana diperoleh bahwa CLI berpengaruh positif terhadap tingkat LABA perusahaan, dengan hubungan lemah $(r=0,202)$

OITL berpengaruh positif dalam meningkatkan LABA perusahaan secara regresi sederhana sebesar $4,0804 \%$ dengan demikian masih ada faktor lain 95,9166\% yang mempengaruhi tingkat laba perusahaan. 
Secara teori OITL adalah termasuk rasio leverage. Menurut Gitman (2006:64) rasio yang menggambarkan tentang proporsi dari jumlah aktiva yg dipinjamkan kepada perusahaan oleh kreditur.

Hasil penelitian ini mendukung penelitian yang dilakukan oleh $\mathrm{R}$ Adi Setiawan (2011) dan Viktorson Taruh (2012) OIT berpengaruh tidak significant terhadap pertumbuhan laba

d. Pengaruh TAT ( Total asset Turnover)

Berdasarkan hasil penelitian secara regresi sederhana diperoleh bahwa TAT berpengaruh positif terhadap tingkat LABA perusahaan, dengan hubungan lemah $(r=0,216)$

TAT berpengaruh positif dalam meningkatkan LABA perusahaan secara regresi sederhana sebesar 4,6656 \% dengan demikian masih ada faktor lain 95,3344\% yang mempengaruhi tingkat laba perusahaan.

Secara teori TAT adalah rasio aktifitas . Menurut Mamduh (2014 :38) dapat digunakan untuk melihat seberapa besar efisiensi penggunaan asset oleh perusahaan.

Hasil penelitian ini mendukung penelitian yang dilakukan oleh $\mathrm{R}$ Adi Setiawan (2011) dan Viktorson Taruh (2012) TAT berpengaruh tidak significant terhadap pertumbuhan laba

Kalo dilihat dari rata-rata TAT 0,87 bila dibanding rata -rata industri menurut Lukviarman (2006:36) sebesar 1,1 kali, maka TAT perusahan subsektor otomotif dan komponen masih dibawah rata-rata.

e. Pengaruh NPM ( Nett Profit Margin )

Berdasarkan hasil penelitian secara regresi sederhana diperoleh bahwa NPM berpengaruh positif terhadap tingkat LABA perusahaan, dengan hubungan cukup kuat $(\mathrm{r}=0,599)$

NPM berpengaruh positif dalam meningkatkan LABA perusahaan secara regresi sederhana sebesar $35,8801 \%$ dengan demikian masih ada faktor lain $64,1199 \%$ yang mempengaruhi tingkat laba perusahaan.

Secara teori NPM adalah rasio profitabilitas . Menurut Husnan dan Pudjiastuti (2015) rasio ini digunakan untuk mengukur efisiensi suatu perusahaan dalam menggunakan aktivanya, efisiensi ini dikaitkan dengan penjualan yang berhasil diciptakan.Hasil penelitian ini mendukung penelitian yang dilakukan oleh Epri Ayu H (2007), R Adi Setiawan(2011) ,NPM berpengaruh signifikan terhadap pertumbuhan laba.

Kalo dilihat dari rata-rata NPM 3,08\% bila dibanding rata -rata industri menurut Lukviarman (2006:36) sebesar 3,92\%i, maka NPM perusahan subsektor otomotif dan komponen masih dibawah rata-rata.

f. Pengaruh GPM ( Gross Profit Margin )

Berdasarkan hasil penelitian secara regresi sederhana diperoleh bahwa GPM berpengaruh negatif terhadap tingkat LABA perusahaan, dengan hubungan sangat lemah $(r=0,028)$

GPM berpengaruh negatif dalam meningkatkan LABA perusahaan secara regresi sederhana sebesar $0,0784 \%$ dengan demikian masih ada faktor lain $99,9316 \%$ yang mempengaruhi tingkat laba perusahaan.

Secara teori GPM adalah rasio profitabilitas. Menurut Sutrisno (2013) merupakan rasio laba kotor dibanding penjualan bersih. 
Hasil penelitian ini mendukung penelitian yang dilakukan oleh Meythi (2005) GPM tidak berpengaruh signifikan terhadap pertumbuhan laba

Kalo dilihat dari rata-rata GPM 15,6 \% bila dibanding rata -rata industri menurut Lukviarman (2006:36) sebesar 24,9 \%, maka TAT perusahan subsektor otomotif dan komponen masih dibawah rata-rata.

3. Pengaruh GPM, WCTA, CLI, OITL, TAT,NPM dan GPM secara simultan Secara Multiple regression ( $\mathrm{r}$ ) adalah 0,824, artinya korelasi antara variabel WCTA, CLI, OITL, TAT, NPM dan GPM dengan tingkat LABA adalah positif 0,824 . Korelasi sebesar 0,824 membuktikan bahwa hubungan antara variabel dari WCTA, CLI, OITL, TAT, NPM dan GPM dengan tingkat LABA perusahaan adalah sangat kuat. (Nilai Adjusted $R$ square 0,629 atau 62,9\%. Hal ini menjelaskan bahwa kontribusi variabel WCTA, CLI, OITL, NPM dan GPM terhadap tingkat LABA perusahaan adalah sebesar $62,9 \%$ sedang sisanya $37,3 \%$ dipengaruhi oleh faktor faktor lain yang tidak diteliti. Dengan demikian dari WCTA, CLI, OITL, TAT, NPM dan GPM apabila dilakukan bersama -sama maka akan meningkatkan kinerja perusahaan sebesar $62,9 \%$.

\section{Simpulan}

Berdasarkan hasil penelitian dikemukakan simpulan sebagai berikut :

1. Rasio WCTA terbesar adalah 42,59 \% PT LPIN pada tahun Desember 2010 sedang terkecil $-46,70 \%$ pada PT NIPS pada Desember 2010. Rasio CLI terbesar 492,9\% pada ASII Desember 2013, terkecil 70,34\% pada INDS Desember 2012. Rasio OITL terbesar 93,96\% pada P T SMSC Desember 2014 dan terkecil 4,39\% pada PT GDYR Des 2015. Rasio TAT terbesar 1,64 pada PT GDYR Desember 2012 dan terkecil 0,23 pada PT PRAS Desember 2016. Rasio NPM terbesar19,59 \% pada PT AUTO Desember 2010 dan terkecil pada PT LPN -45.76\%. Rasio GPM terbesar pada PT LPIN 43,99\% pada Desember 2011 dan terkecil pada PT GDYR sebesar $6,76 \%$.

2. Pengaruh rasio WCTA ( Working Capital to Total asset) terhadap tingkat Laba berpengaruh positif sebesar 8,0656 \% .Pengaruh rasio CLI ( Current Liability to Inventory) terhadap tingkat Laba berpengaruh positif sebesar $0,1444 \%$. Pengaruh rasio OITL ( Operting income to Total Liability) terhadap tingkat Lababerpengaruh positif sebesar 4,0804\%. Pengaruh rasio TAT ( Total asset Turnover) terhadap tingkat Laba berpengaruh positif sebesar 4,6656 \% .Pengaruh rasio NPM ( Nett Profit Margin ) terhadap tingkat Laba berpengaruh positif seesar 35,8801\%. Pengaruh rasio GPM ( Gross Profit Margin ) terhadap tingkat Laba berpengaruh negatif sebesar $0,0784 \%$. Hanya rasio NPM yang mempunyai signifikansi sangat kuat.

3. Berdasarkan penelitian secara bersama- sama WCTA, CLI, OITL, TAT, NPM dan GPM bersama sama memiliki pengaruh yang signifikan terhadap tingkat Laba. Kontribusi yang diberikan variabel WCTA, CLI, OITL, TAT, NPM dan GPM terhadap tingkat Laba sebesar 0,629atau 62,9 \%. Hal ini menjelaskan bahwa kontribusi variabel WCTA, CLI, OITL, TAT, NPM dan GPM terhadap tingkat LABA perusahaan adalah sebesar $62,9 \%$ sedang sisanya $37,1 \%$ dipengaruhi oleh faktor faktor lain yang tidak diteliti. Dengan demikian dari WCTA, CLI, OITL, TAT, NPM dan GPM apabila dilakukan bersama -sama maka akan meningkatkan kinerja perusahaan sebesar $62,9 \%$. 


\section{Saran-saran}

Berdasar hasil kesimpulan dan pembahasan pada $b a b=b a b$ sebelumnya dapat dikemukakan beberapa saran yang diharapkan dapat berguna bagi pihak terkait sebagai berikut :

1. WCTA memiliki pengaruh terhadap tingkat Laba perusahaan walaupun tidak signifikan, maka sebaiknya perusahaan tetap menjaga rasio WCTA stabil atau lebih besar karena rasio ini menunjukkan kemampuan perusahaan untuk memenuhi kewajiban finansialnya, perlu diperhatikan pada perusahaan yg rasio WCTA nya masih negatif.

2. CLI memiliki pengaruh terhadap tingkat Laba perusahaan yangtidak signifikan, namun sebaiknya perusahaan tetap menjaga rasio stabil atau lebih kecil karena rasio ini menunjukkan seberapa jauh perusahaan menggunakan hutang.

3. OITL memiliki pengaruh terhadap tingkat Laba perusahaan walaupun tidak signifikan, maka sebaiknya perusahaan tetap menjaga rasio stabil atau lebih besar karena rasio ini menunjukkan seberapa jauh perusahaan mendapatkan income dari menggunakan hutang

4. TAT memiliki pengaruh terhadap tingkat Laba perusahaan walaupun tidak signifikan, maka sebaiknya perusahaan tetap menjaga rasio stabil atau lebih besar karena rasio ini menunjukkan seberapa jauh perusahaan membuat efisiensi penggunaan.

5. NPM memiliki pengaruh terhadap tingkat Laba perusahaan sangatsignifikan ,maka sebaiknya perusahaan tetap menjaga rasio stabil atau lebih besar karena rasio ini menunjukkan seberapa jauh membuat efisiensi dengan menggunakan aktivanya dengan penjualan yang berhasil diciptakan.

6. GPM memiliki pengaruh terhadap tingkat Laba perusahaan walaupun tidak signifikan ,maka sebaiknya perusahaan tetap menjaga rasio stabil atau lebih besar karena rasio ini termasuk rasio profitabilitas menunjukkan seberapa jauh membuat efisiensi dengan menggunakan aktivanya dengan penjualan yang berhasil diciptakan.

7. Laba perusahaan dipengaruhi oleh banyak faktor, diantarnya WCTA, CLI, OITL, TAT, NPM dan GPM yang menyubang determinasi $62,8 \%$. Perlu di teliti faktor diluar itu yang lebih signifikan untuk mendorong tingkat laba perusahaan.

\section{Daftar Pustaka}

Ade Gunawan dan Srifitri Wahyuni, “ Pengaruh rasio keuangan terhadap pertumbuhan laba pada perusahaan perdagangan di Indonesia”, Jurnal Manajemen \& Bisnis Vol 13 No 01 April 2013, ISSN 1693-7619

Ciaran Walsh 2012 , Key Management Ratios, Edisi IV, Esensi Erlangga

Danang Sunyoto 2012, Prosedur Uji Hipotesis untuk riset Ekonomi, Alfabeta

E. Ayu Hapsari 2007, Analisis rasio keuangan untuk memprediksi pertumbuhan laba , studi kasus : Perusahaan manufactur yang terdaftar di BE Jakarta 2001-2005, Undip

Eddy Herjanto 2008 , Manajemen Operasi edisi III, Grasindo

Firdaus, Muhammad 2008, Manajemen Agribisnis, Jakarta , Bumi Aksara

Hendra Agus Wibowo dan Diyah Pujiati, "Analisa Rasio Keuangan dalam memprediksi pertumbuhan laba pada perusahaan Real estate dan property di 
BEI dan SGX", The Indonesian Accounting review, Vol1 No2 july 2011 , page 155-178

Hery 2016, Financial Ratio For Business : Analisis Keuangan untuk menilai Kondisi Financial dan kinerja Perusahaan, Grasindo

Husnan, SuaddanEnnyPudjiastuti, 2015, Dasar-dasarManajemenKeuangan, UPP.AMP. YKPN

Jonathan Sawono, 2013, Model-model Linier dan non Linier dalam IBM SPSS 21, Elex Media Komputindo

Jumingan 2014, Analisis Laporan Keuangan Bumi Aksara

Lawrence J. Gitman dan Chad J. Zutter 2010 , Managerial Finance, 13th, Prentice Hall Pearson

Mamduh M. Hanafi, 2014 ,Manajemen Keuangan, Bpfe FEUGM

Martin Fridson, Fernando Alvares 2002 , Financial statement analysis: a Practioners Guide, 3th edition, Wileyfinance

Meythi , Tan Kwan En, Linda Rusli 2011 , Pengaruh likuiditas dan profitibilitas terhadap harga saham Perusahaan manufaktur yang terdaftar di Bursa Efek Indonesia ,Jurnal Bisnis Manajemen dan Ekonomi, Vol 10 No 2 Mei, hal 26712684, ISSN 1693-8305

Meythi, 2005,"Rasio Keuangan yang paling baik Untuk Memprediksi Pertumbuhan Laba: Suatu studi Empiris Pada Perusahaan Manufaktur Yang Terdaftar Di Bursa Efek Jakarta", JurnalEkonomidanBisnis Vol. XI No. 2, September

Meythi, 2007 , “ Rasio Keuangan yang paling baik sebagai prediktor resiko Sistemik : Suatu studi empiris perusahaan Manufaktur yang terdaftar di BEJ", Jurnal ilmiah Akuntasi Vol 6 No 2 November 2007: 1-23

Meythi, 2013, Rasio Keuangan terbaik untuk memprediksi Nilai Perusahaan, Jurnal keuangan dan Perbankan Vol 17 No 2, Mei , hal 200 - 210, Terakreditisasi SK No 84a/Dikti/Kep/2010

Michel C. Enrhart dan Eugene T. Brigham, 2011, Financial Management, Theory \& Practice, South western, GenCage Learning

Munawir, S 2014. Analisis Laporan Keuangan Edisi Keempat. Liberty

R. Adi Setiawan 2011, Analisis Pengaruh Kinerja Keuangan dalam memprediksi Pertumbuhan Laba, FEUB, Jurnal Aplikasi Manajemen Vol 10,No 3 , hal 669681, ISSN 1693-5241

Riyanto, Bambang, 2015, Dasar-dasar Pembelanjaan Perusahaan Edisi 4, BPFE Ross, Westerfield dan Talle 2003, Corporate Finace 6th , McGrawHill Prmisonline Sofyan Safri Harahap 2013, Analisis kritis atas Laporan Keuangan, Raja Grafindo Persada, Jakarta,

Sugiyono 2012 , Metode Penelitian Kuantitatif, Kualitatif dan R\&D , Alfabeta

Sutrisno 2013 , Manajemen Keuangan, Teori Konsep dan Aplikasi , Ekonesia FEUII

Tubagus Achmad Darodjat 2015 , Konsep - Konsep dasar Manajemen Personalia Masa Kini, Refika Aditama. 